Е.А. Пальмова // Российский психологический журнал. - Том 8. 2011. - № 2. - C. 21.

8. Оценка программ: методология и практика / под ред. А.И. Кузьмина, Р. О’Салливан, Н. А. Кошелевой. - Москва : Издательство «Престо-РК», 2009. - 256 с.

9. Оцінювання в школі [ред. Е. Толвінська-Круліковська]. Варшава: ОРО, 2010.

DOI https://doi.org/10.30525/978-9934-588-80-8-2.9

\title{
THE IMPORTANCE OF A FOREIGN LANGUAGE FOR DEVELOPING THE PROFESSIONAL COMPETENCE OF THE POST-GRADUATES
}

\author{
Zelenska O. P. \\ Doctor of Pedagogical Sciences, Professor, \\ Professor at the Department of Foreign Languages \\ and Culture of Professional Speech \\ Lviv State University of Internal Affairs \\ Lviv, Ukraine
}

The aim of learning a foreign language by the post-graduates taking the non-linguistic post-graduate course is forming the foreign language professionally oriented communicative competence that makes it possible for them to integrate into the international professional environment and use the professional foreign language as a means of intercultural and professional communication. Learning the foreign language must concentrate on improving of learning the types of the speech activity (speaking, reading, auditing, and writing) that comes down to forming the communicative speech competence in these types, which consists of the lingual competence (lexical, phonological, and syntactic skills and habits), the socio-lingual competence (the socio-cultural conditions of the language usage), the pragmatic competence (the functional usage of the linguistic means: the language functions, speech acts production, etc.), the professional competence (the readiness and ability of the specialist to analyze and practically solve the important professional problems independently on the basis of the consciously acquired knowledge, skills, experience, and all personal inner resources), the cognitive competence (the readiness to raise one's own educational level constantly, the need of the actualization and 
realization of the personal potential, the ability to acquire new knowledge independently, the desire for self-development). Just through this communicative speech competence speech communication is realized.

The process of learning the foreign language enables the post-graduates' forming and improving the skills and habits of the academic work, preparing for and carrying out the scientific research work, writing the scientific papers, discussing the themes of the scientific research and the results of the ready scientific papers, conducting the scientific discussion and presenting the results of the research, writing the essays and summaries, carrying out the essay and annotative translations of the scientific literature, processing the scientific papers and results of the research, preparing the reports, and presentations, taking part in the scientific conferences, seminars, workshops and round tables [2].

The subject of learning the foreign language is the language and speech operations and actions on the level of phonetics, orthography, lexis, grammar and stylistics, various types of the speech activity (reading, speaking, auditing, and writing); culturological knowledge, and the peculiarities of the verbal and non-verbal behaviour of the native speakers. The course of the foreign language for those who take the post-graduate course has a communicatively oriented and professionally directed character taking into account the continuity and succession of the different stages of speech mastering (of the system 'school - establishment of higher education'). The peculiarity of mastering the foreign language at this stage is the fact that speech and science acquisition takes place at the same time, and it is considered to be the discourse practice, and the language acts as the form of scientific knowledge in accordance with the conditions of scientific communication. The important task of the foreign language training of the post-graduates is their knowledge of the structure of the scientific discourse, possession of the strategies of its construction, forms and means of scientific communication. Mastering the foreign language is a factor of fostering the development of a range of the universal, general professional and special professional competences.

Such scholars as S. Bim, N. Gez, N. Gershunsky, N. Goncharova, I. Zimnyaya, G. Kitaygorodskaya, V. Lyashenko, R. Milrud, Yu. Passov, R. Epstein, E. Hundert, G. Moskowitz, M. Mulder, R. Scarcella, E. Stewick, E. Tarone D. Yule and others considered the issues of the professional foreign language communicative competence, professionally oriented teaching of the foreign language, the formation of the main competences, particularly professional and scientific ones. But the problem of training the qualified post-graduates taking the non-linguistic post-graduate course, 
forming their professional competence using the foreign language is a topical one and needs to be studied and discussed.

The competence is the characteristic of the individual intellectual resources that foresees the high level of acquiring the various types of knowledge, including knowledge in the concrete subject sphere, the formation of the certain qualities of thought, the motivation of this type of activity, the readiness to make a decision concerning the particular situations, and the system of valuables [3]. The foreign language helps to develop the skills to inform, to describe, to explain, to analyze, to comment, to prove, to disprove, etc.

The professional competence of a specialist is a complex individual psychological formation on the basis of integrating experience, theoretical knowledge, important individual qualities that condition his/her readiness to carry out the topical professional activity [1]. The professional competence is a general, integrative and inner ability to carry out a continuous efficient (proper) activity (including solving the problems, realizing innovations and carrying out changes) in a particular professional sphere, work, role, organizational context and given situation [4].

Considering the professional competence which is formed using the foreign language we should mention the following issues:

- the ability to form the foreign language professionally oriented communicative competence that makes it possible to integrate into the international professional environment and use the professional foreign language as a means of intercultural and professional communication;

- the ability to master the foreign language as a means of acquiring, broadening and improving knowledge in speciality, its usage with the practical aims for the needs of one's speciality, i.e. as a means of the independent improving one's qualification;

- the ability to understand, speak and create the texts in the foreign language using the professional vocabulary, phraseology, stylistic and rhetorical strategies, to improve the skills and habits in all the types of the speech activity (reading, speaking, auditing, and writing);

- the ability to use basic knowledge of the foreign language in the professional and cognitive activity for understanding the essence of the information in the modern society, to orient in the main information processes;

- the ability to acquire and use new knowledge and skills in the practical activity, to improve and broaden the scientific world outlook by means of the foreign language; 
- the ability to use knowledge of the foreign language for designing and carrying out the socially important scientific projects;

- the ability to have interdisciplinary interaction and to cooperate with the specialists from other countries in the various situations of professional communication that is carried out in the form of oral and written communication using the foreign language not only directly, but also through the media means for solving the scientific research and practical tasks;

- the ability to analyze, synthesize and critically apprehend the necessary information with the help of the professional foreign language using authentic sources for solving the various scientific and practical tasks;

- the ability using the foreign language to analyze, summarize and systematize the data of the scientific research on the basis of the modern interdisciplinary approaches;

- the ability to use during the research the thematic net resources, data basis, information research systems, having access to the foreign electronic libraries and digital archives.

Thus, the post-graduates taking the non-linguistic post-graduate course:

- improve the former acquired skills and habits in all the types of speech activity and forms of communication in the foreign language and use them as the basis for developing the communicative competence in the sphere of the scientific and professional activity;

- carry out speech communication according to the basis of intercultural scientific communication; improve the vocabulary necessary for the scientific and professional activity in compliance with the speciality and directions of the scientific activity using the foreign language;

- develop the professionally important competence of foreign language communication in all the types of the speech activity for practical scientific and professional communication; improve the skills and habits of the independent work to raise the level of mastering the foreign language and to carry out the scientific and professional activity using the foreign language;

- realize the acquired speech skills in the process of searching, choosing and using the foreign language materials for their scientific work (papers, theses) and oral presentation of the research.

\section{References:}

1. Валеева Н.Ш., Хасанова Г.Б. Профессионализм специалиста социальной работы: компетентностный подход: монография. Казань: Казан. гос. технол. ун-т. 2008. 229 с.

2. Зеленська О.П. Деякі особливості навчання іноземної мови в нелінгвістичній аспірантурі (ад’юнктурі). Вища освіта України у 
контексті інтеграції до європейського освітнього простору. К.: Гносиз, 2019. № 4. Кн. 2. Т. 3 (85). С. 93-101.

3. Расширенный текст доклада профессора М.А. Холодной на IV Всероссийском съезде психологов образования России «Психология и современное российское образование» [Электронный ресурс]. - URL: http://ipras.ru/cntnt/rus/novosti/rus_news1/n2742.html

4. Mulder M. Conceptions of professional competence // International handbook of research in professional and practice-based learning. Dordrecht: Springer. 2014. P. 107-137.

DOI https://doi.org/10.30525/978-9934-588-80-8-2.10

\title{
PERSONALITY-CENTERED APPROACH TO THE DEVELOPMENT OF INFORMATION AND ANALYTICAL COMPETENCY OF FUTURE SECURITY SECTOR SPECIALISTS
}

\author{
Karasova L. A. \\ Candidate of Pedagogic Sciences, \\ Senior Lecturer at the Department of Romance and Germanic Languages \\ National Academy of the Security Service of Ukraine \\ Hromova N. M. \\ Candidate of Psychological Sciences, \\ Senior Lecturer at the Department of Romance and Germanic Languages \\ National Academy of the Security Service of Ukraine

\section{Tsviak L. V.} \\ Candidate of Philological Sciences, Associate Professor \\ Professor at the Department of Foreign Languages \\ Bohdan Khmelnytskyi National Academy \\ of the State Border Guard Service of Ukraine \\ Khmelnytskyi, Ukraine
}

There have been disputes over the problem of development of information and analytical competency of future specialists in the works of the educators, sociologists, psychologists, philosophers. Information and analytical competency is one of the main components of professional competency particularly that of future security sector specialist. The conceptual basis of the study is a personality-centered approach, which has allowed substantiating the theoretical and methodological prerequisites to 